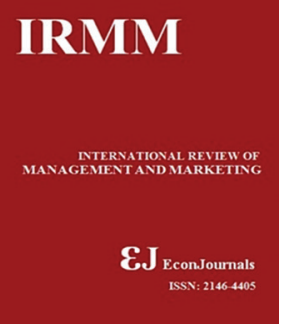

\section{International Review of Management and Marketing}

ISSN: $2146-4405$

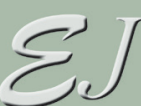

Econdowrnals

available at http: www.econjournals.com

International Review of Management and Marketing, 2021, 11(1), 92-97.

\title{
Knowledge Management and Green Commitment Analysis of Green Behavior Employee and its Implication on Sustainability Corporate in Banking
}

\author{
Lenny Christina Nawangsari*, Ahmad Hidayat Sutawijaya, Ade Maharini, Hendra Winata \\ Universitas Mercu Buana, Jakarta, Indonesia. *Email: a.h.sutawijaya@mercubuana.ac.id
}

Received: 17 August 2020

Accepted: 10 January 2021

DOI: https://doi.org/10.32479/irmm.10467

\begin{abstract}
This study aims to analyze the effect of knowledge management, green commitment and employee green behavior on organizational sustainability in banking institutions. The research method used is a qualitative method with the object of employee research at banking institutions in Indonesia. This study used a sample size of 150 people. Data analysis used SEM (structural equation model) with PLS (partial least square) software. The results of the study provide information about the influence of knowledge management, green commitment and green employee behavior on organizational sustainability in banking institutions.
\end{abstract}

Keywords: Banking, Knowledge Management, Green Employee Behavior, Organizational Sustainability

JEL Classification: G2, L2

\section{INTRODUCTION}

Sustainability banking/financial sustainability organizations remain a new challenge to be applied in the financial services system in Indonesia, particularly in the banking sector. One of the principles of sustainable finance is Human Resources, which is the main driver of sustainable economic growth.

Banking as a financial institution, needs to prepare professional and qualified Human Resources who are able to apply sustainable financial principles so as to create products/services as an effort to improve services to customers in the banking sector.

Based on the survey found that the Sustainability of Organizations related to 3P (Profit, People and Planet) has not been maximized in banking. From several previous studies found variables that affect Organizational Sustainability are Knowledge Management (Mostafa, 2010; Rosemary and Sinnappan, 2008;
Vasja et al., 2014; Wijethilake, 2017), Green Commitments (Jansson et al., 2017; Abdelghafour et al., 2018) and employee green behavior (Qaisar et al., 2018).

Based on the foregoing, a research related to Knowledge Management and Green Commitment Analysis on Employee Green Behavior and its implications for corporate sustainability in Banking.

\section{LITERATURE REVIEW}

\subsection{Knowledge Management}

Knowledge Management is a systematic coordination within an organization that manages human resources, technology, processes and organizational structures in order to increase value through reuse and innovation. This coordination can be achieved through creating, sharing and applying knowledge by using the experience and actions taken by the company for the continuity 
of organizational learning. Dalkir (2011). There are two types of knowledge contained in the company are Tacit Knowledge and Explicit Knowledge is knowledge.

\subsection{Green Commitment}

Employees who are committed to the organization are a situation where there is a sense of ownership, defending and fighting as hard as possible, time and thought for the progress of the organization in achieving the ideals expected together (Robbins and Judge, 2009: 100). The existence of a high commitment attitude, employees voluntarily do earnestly what the goals and interests of the organization. They will do everything consciously such as behaving in an environmentally friendly manner and so on which is the organization and government program (Morrow, 2011).

\subsection{Employee Green Behaviour}

To identify the green behavior of ones and Dilchert (2012) employees in Norton (2014) developed five broad functional categories of employee green behavior which include: Efficiency. Control, Caring for the environment, motivation and intention of positive behavior.

\subsection{Corporate Sustainability}

Sustainable corporate performance is performance that can be achieved on condition that companies must consider reducing environmental footprints, and start paying attention to social, environmental, economic, and financial factors to succeed in the corporate sector. furthermore, it is possible to achieve earnings by shareholders (Boiral and Paillé, 2011; Daily et al., 2009). The company's sustainability performance is also measured through the efficient use of resources, increasing cost advantages, reducing waste and disposal, promotion. Environmental performance from social reputation, improved customer preferences, and the generation of new innovative capabilities (Bhupendra and Sangle, 2015).

The research framework is as shown in Figure 1.

\section{RESEARCH METHODS}

This type of research is quantitative research. The object of this research is conducted at the Banking Institution in Indonesia. The sample in this study was 150 people. The technique of sampling is random sampling and data analysis uses SEM/PLS.

Figure 1: Research framework

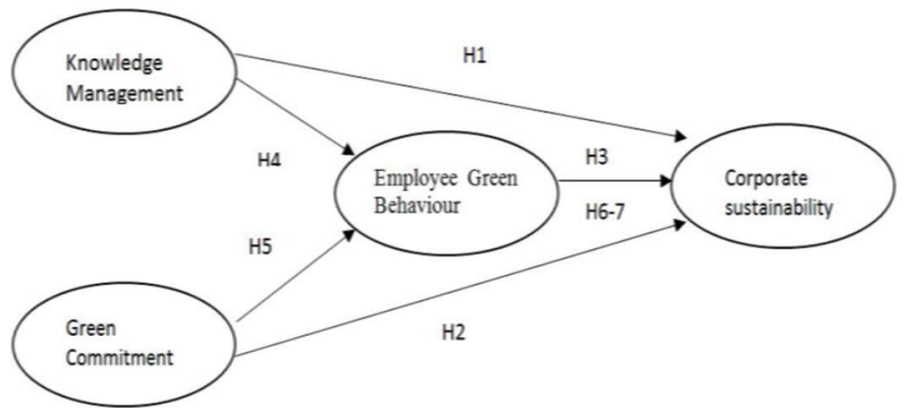

Source: Primary data processed, 2020

\section{ANALYSIS AND DISCUSSION}

\subsection{Convergent Validity Testing}

Table 1 show the result of testing after the indicator that has an outer loading value $\leq 0.7$ Thus, the indicator fulfils the convergent validity criteria that is feasible.

\subsection{Discriminant Validity}

The Table 2 shows the results of the discriminant validity test where all the values of Average variance extracted (AVE) are more than 0.50 . Thus it can be concluded that this measurement meets Convergent Validity requirements based on the value of average variance extracted (AVE).

\subsection{Composite Reliability}

Based on the Table 3, it can be explained the results of composite reliability testing that shows satisfactory values, where all latent variables have been reliable because all the values of the variables have composite reliability values $\geq 0.70$. In other words, the questionnaire used as an instrument in this study is reliable or

Table 1: Convergent validity model test results

\begin{tabular}{lccc} 
Variable & Indicator & Outer loading & Note \\
Knowledge & X1.1.2 & 0.884 & Valid \\
management (X1) & X1.3 & 0.882 & Valid \\
& X1.4 & 0.891 & Valid \\
Green & X2.1 & 0.910 & Valid \\
commitment (X2) & X2.2 & 0.916 & Valid \\
& X2.3 & 0.714 & Valid \\
Employee green & Y1.1 & 0.882 & Valid \\
behavior (Y1) & Y1.2 & 0.902 & Valid \\
& Y1.3 & 0.805 & Valid \\
Sustainable & Y1.5 & 0.889 & Valid \\
corporate & Y2.1 & 0.852 & Valid \\
performance (Y2) & & & \\
& & & \\
& Y2.2 & 0.855 & Valid \\
& Y2.3 & 0.780 & Valid \\
\hline
\end{tabular}

Source: Primary data processed, 2020

Table 2: Discriminant validity test results

\begin{tabular}{lc} 
Variable & Average variance extracted \\
Knowledge management (X1) & 0.784 \\
Green commitment (X2) & 0.726 \\
Employee green behaviour (Y1) & 0.758 \\
Sustainable corporate & 0.689 \\
performance (Y2) & \\
\hline
\end{tabular}

Source: Primary data processed, 2020

Table 3: Composite reliability test result

\begin{tabular}{lcc} 
Variable & Composite reliability & Note \\
$\begin{array}{l}\text { Knowledge } \\
\text { management (X1) }\end{array}$ & 0.916 & Reliable \\
$\begin{array}{l}\text { Green } \\
\text { commitment (X2) }\end{array}$ & 0.887 & Reliable \\
$\begin{array}{l}\text { Employee green } \\
\text { behaviour (Y1) }\end{array}$ & 0.926 & Reliable \\
$\begin{array}{l}\text { Sustainable corporate } \\
\text { performance (Y2) }\end{array}$ & 0.869 & Reliable \\
\hline
\end{tabular}

Source: Primary data processed, 2020 
consistent. Thus it can be concluded that, all indicators are indeed a measure of their respective constructs.

\subsection{Goodness of Fit Model}

This study uses a structural equation model of the partial least square (PLS) approach. Before analyzing, testing or evaluating an empirical model of research is first carried out. The results of testing the empirical model of this study can be seen in the visualization of Figure 2 as follows:

\subsection{Structural Model Testing (Outer Model)}

The results of hypothesis testing using Smart PLS 3.2.8 software can be seen in Table 4 and Figure 3 as follows:

Hypothesis testing in this study are as follows:

1. There is a significant influence of knowledge management (X1) on sustainable corporate performance (Y2)

Based on Table 4, it is known that the value of $t$ statistics is 21,933 which is greater than the value of $t$ table $=2.265$, and the value of $\mathrm{P} \leq 0.000$ which is smaller than $\alpha=0.05$. The coefficient value is positive that is equal to 0.511 means that the knowledge management variable (X1) has a positive effect on the Sustainable corporate performance variable (Y2) of 51.1\%. Thus the H1 hypothesis in this study which states that "Knowledge Management (X1) has a significant effect on Sustainable Corporate Performance (Y2)" is accepted.

2. There is a significant effect of green commitment (X2) on sustainable corporate performance (Y2)

Based on Table 4, it is known that the value of $t$ statistics is 6.796 which is greater than the value of $t$ table $=2.265$, and the value of $\mathrm{P}=0.007$ which is smaller than $\alpha=0.05$. The coefficient value is positive that is equal to 0.201 meaning that the green commitment (X2) variable has a positive effect on the sustainable corporate performance (Y2) variable of $20.1 \%$. Thus the $\mathrm{H} 2$ hypothesis in this study which states that "Green
Commitment (X2) has a significant effect on Sustainable Corporate Performance (Y2)" is accepted.

3. There is a significant effect of employee green behavior (Y1) on sustainable corporate performance (Y2)

Based on Table 4, it is known that the value of $t$ statistics is 34.151 which is greater than the value of $t$ table $=2.265$, and the value of $\mathrm{P} \leq 0.000$ which is smaller than $\alpha=0.05$. The coefficient value is positive that is equal to 0.28 meaning that the employee green behavior (Y1) variable has a positive effect on the sustainable corporate performance variable (Y2) of $28 \%$. Thus the $\mathrm{H} 3$ hypothesis in this study which states that "Employee Green Behavior (Y1) has a significant effect on Sustainable Corporate Performance (Y2)" is accepted.

4. There is a significant effect of knowledge management (X1) on employee green behavior (Y1)

Based on Table 4, it is known that the value of $t$ statistics is 29.297 which is greater than the value of $t$ table $=2.265$, and the value of $\mathrm{P} \leq 0.000$ which is smaller than $\alpha=0.05$. The coefficient value is positive that is equal to 0.75 meaning that the knowledge management (X1) variable has a positive effect on the employee green behavior (Y1) variable by $75 \%$. Thus the $\mathrm{H} 4$ hypothesis in this study which states that "Knowledge Management (X1) has a significant effect on Employee Green Behavior (Y1)" is accepted.

5. There is a significant effect of green commitment (X2) on employee green behavior (Y1)

Based on Table 4, it is known that the value of $t$ statistics is 10.505 which is greater than the value of $t$ table $=2.265$, and the value of $\mathrm{P}=0.002$ which is smaller than $\alpha=0.05$. The coefficient value is positive, that is 0.294 , it means that the green commitment (X2) variable has a positive effect on the employee green behavior (Y1) variable of $29.4 \%$. Thus the $\mathrm{H} 5$ hypothesis in this study which states that "Green Commitment (X2) has a significant effect on Employee Green Behavior (Y1)" is accepted.

Figure 2: Results of analysis with PLS

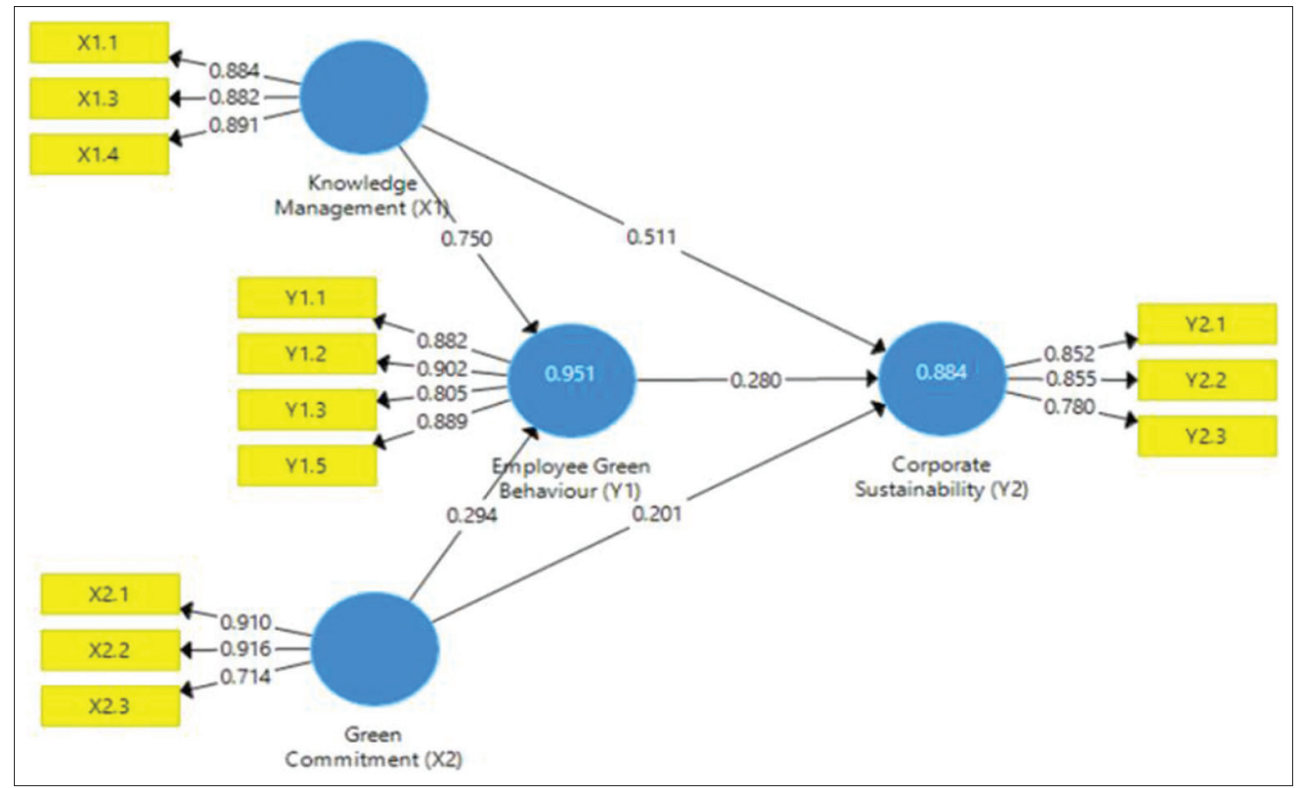

Source: Primary data processed, 2020 
Table 4: Path coefficient, t-statistics, and P-values

\begin{tabular}{|c|c|c|c|c|}
\hline & Original Sample (O) & T Statistics (|O/STDEV|) & P-values & Note \\
\hline \multicolumn{5}{|l|}{ Direct influence } \\
\hline $\begin{array}{l}\text { Knowledge management }->\text { sustainable corporate } \\
\text { performance }\end{array}$ & 0.511 & 21,993 & $<0.000$ & $\begin{array}{l}\text { Significantly } \\
\text { positive influence }\end{array}$ \\
\hline $\begin{array}{l}\text { Green commitment }->\text { sustainable corporate } \\
\text { performance }\end{array}$ & 0.201 & 6796 & 0.007 & $\begin{array}{l}\text { Significantly } \\
\text { positive influence }\end{array}$ \\
\hline $\begin{array}{l}\text { Employee green behaviour }->\text { sustainable } \\
\text { corporate performance }\end{array}$ & 0.280 & 34,151 & $<0.000$ & $\begin{array}{l}\text { Significantly } \\
\text { positive influence }\end{array}$ \\
\hline $\begin{array}{l}\text { Knowledge management }->\text { employee green } \\
\text { behaviour }\end{array}$ & 0.750 & 29,297 & $<0.000$ & $\begin{array}{l}\text { Significantly } \\
\text { positive influence }\end{array}$ \\
\hline Green commitment -> employee green behaviour & 0.294 & 10,505 & 0.002 & $\begin{array}{l}\text { Significantly } \\
\text { positive influence }\end{array}$ \\
\hline \multicolumn{5}{|l|}{ Indirect influence } \\
\hline $\begin{array}{l}\text { Knowledge management }->\text { employee green } \\
\text { behaviour }->\text { sustainable corporate performance }\end{array}$ & 0.210 & 30,083 & $<0.000$ & $\begin{array}{l}\text { Significantly } \\
\text { positive influence }\end{array}$ \\
\hline $\begin{array}{l}\text { Green commitment }->\text { employee green } \\
\text { behaviour }->\text { sustainable corporate performance }\end{array}$ & 0.082 & 11,681 & 0.001 & $\begin{array}{l}\text { Significantly } \\
\text { positive influence }\end{array}$ \\
\hline \multicolumn{5}{|l|}{ Total influence } \\
\hline $\begin{array}{l}\text { Knowledge management }->\text { employee green } \\
\text { behaviour }->\text { sustainable corporate performance }\end{array}$ & 0.721 & 38,656 & $<0.000$ & $\begin{array}{l}\text { Significantly } \\
\text { positive influence }\end{array}$ \\
\hline $\begin{array}{l}\text { Green commitment }->\text { employee green } \\
\text { behaviour -> sustainable corporate performance }\end{array}$ & 0.283 & 12,271 & 0.001 & $\begin{array}{l}\text { Significantly } \\
\text { positive influence }\end{array}$ \\
\hline
\end{tabular}

Source: Primary data processed, 2020

6. There is a significant influence of knowledge management (X1) on sustainable corporate performance (Y2) through the employee green behavior (Y1) variable

Based on Table 4, it is known that the value of t statistics for the Knowledge Management variable is 30.083 which is greater than the value of table $=2.265$, and the value of $\mathrm{P} \leq 0.000$ which is smaller than $\alpha=0.05$. The coefficient value is positive that is equal to 0.21 meaning that the knowledge management (X1) variable has a positive effect on the sustainable corporate performance (Y2) variable through the Employee Green Behavior (Y1) by 21\%. Thus the H6 hypothesis in this study which states that "Knowledge Management (X1) has a significant effect on Sustainable Corporate Performance (Y2) through Employee Green Behavior (Y1)" is accepted.

7. There is a significant influence of green commitment (X2) on sustainable corporate performance (Y2) through the employee green behavior (Y1) variable

Based on Table 4, it is known that the value of $t$ statistics for the Green Commitment variable is 11.681 which is smaller than the value of $t$ table $=2.265$, and the value of $\mathrm{P}=0.001$ is greater than $\alpha=0.05$ so that the green commitment variable (X2) has a positive effect on variable sustainable corporate performance (Y2) through Employee Green Behavior (Y1). Thus the H7 hypothesis in this study which states that "Green Commitment (X2) has a significant effect on Sustainable Corporate Performance (Y2) through Employee Green Behavior (Y1)" is accepted.

\section{DISCUSSION}

\subsection{Knowledge Management Affects Sustainable Company Performance}

This study proves that knowledge management has an effect on sustainable company performance. This research is in line with
Figure 3: Testing the indirect effect with smart PLS

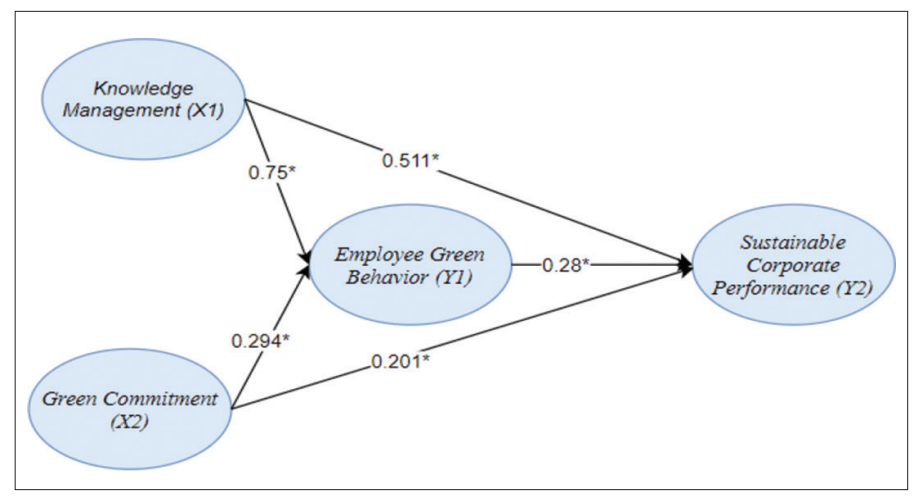

Source: Primary data processed, 2020

the research of Nejati et al. (2010) and Ghabash et al. (2018) which states that knowledge management has an effect on organizational sustainability. Knowledge Management The dimension that has the greatest influence is Knowledge Application. Based on observations on the object of research, employees can help in making organizational decisions with the knowledge they have. In addition, the organization also provides a repository of new knowledge media that employees use.

\subsection{Green Commitment has an Effect on Sustainable Company Performance}

The results of this study prove the influence of green commitment on sustainable company performance. This research is in line with the research of Ali et al. (2018) which states that green commitment has a positive effect on employee green behavior. The dimension of Green Commitment that has the highest influence is normative commitment. According to employees moving from organizations that pay attention to environmental sustainability to other organizations that are not ethical and feel better able to work in an environmentally friendly organization throughout their career. 


\subsection{Employee Green Behavior has an Effect on Sustainable Company Performance}

This research proves that the Green Behavior of Employees has an effect on Sustainable Company Performance. The results of this study support the research of Qaisar et al. (2018) which proves that employee green behavior has an effect on environmental sustainability. The highest research dimension of Employee Green Behavior is Task Control. It shows the actions of the organization and its employees in managing waste and minimizing environmental impact. The lowest dimension of Employee Green Behavior is related to efficiency. Organizations are expected to make more use of natural resources in their work. In addition, organizations also need to maximize their own resources so that no resources are wasted.

\subsection{Knowledge Management Affects Employee Green Behaviour}

The results of this study prove that knowledge management has an effect on employee green behaviour. The results of this study support the research of Rosemary and Sinnappan (2008) which states that knowledge management has an effect on employee green behaviour. The lowest dimension of knowledge management is knowledge sharing. Research proves that organizations have not been optimal in fostering a culture of knowledge transfer among employees. With the knowledge transfer culture, employees get knowledge from their superiors and colleagues in order to improve their performance.

\subsection{Green Commitment Affects the Employee Green Behaviour}

This study proves that green commitment has an effect on employee green behaviour. Thanita's research (2017) and Toha and Lenny (2019) supports the results of this study. This study states that there is a positive relationship between green commitment and employee green behaviour. The lowest dimension of green commitment is continuance commitment. Employees are still worried about what might happen if they leave an environmentally conscious organization without having another similar job. They also consider that one of the serious consequences of leaving an organization that is concerned with environmental sustainability is the scarcity of alternative opportunities that exist.

\subsection{Knowledge Management Affects Sustainable Corporate Performance through the Employee Green Behaviour}

The results of this study prove that Knowledge Management has a greater effect on Sustainable Corporate Performance through the Employee Green Behaviour. This research is in line with the research of Ghabash et al. (2018) which states that Organizational Learning has a direct effect on Employee Green behaviour. Other supporting research is research by Vasja et al. (2014) and Nejati et al. (2010) which states that knowledge management has an effect on sustainable development and research. The highest dimension of sustainable corporate performance is economic sustainable. In this study it is stated that the organization has collaborated with government officials to protect the environmental interests of the company. In addition, the organization has also reduced input costs for the same level of output.

\subsection{Green Commitment Affects Sustainable Corporate Performance through the Employee Green Behaviour}

This study proves that green commitment has a greater effect on sustainable corporate performance through the employee green behaviour variable. The results of this study are in line with Bilal and Umrani's research (2019) which states that environmental commitment has an effect on pro-environmental behaviour and research by Abdelghafour et al. (2018) which states the importance of environmental commitment for organizational sustainability. In sustainable corporate performance, the lowest dimension is sustainable social. This means that the organization must further consider the interests of stakeholders in investment by creating a formal dialogue. Besides, it is also necessary to communicate the company's environmental impacts and risks to the public.

\section{CONCLUSION}

1. Knowledge management (X1) has a significant effect on sustainable corporate performance (Y2)

2. Green commitment (X2) significantly influence sustainable corporate performance (Y2)

3. Employee green behavior (Y1) has a significant effect on sustainable corporate performance (Y2)

4. Knowledge management (X1) has a significant effect on employee green behavior (Y1).

5. Green commitment (X2) has a significant effect on employee green behavior (Y1)

6. Knowledge Management (X1) has a significant effect on sustainable corporate performance (Y2) through employee green behavior (Y1)

7. Green commitment (X2) has a significant effect on sustainable corporate performance (Y2) through employee green behavior (Y1).

\section{RECOMMENDATION}

1. Knowledge management

Knowledge management is a variable that is quite important in increasing sustainable corporate performance. Based on the research results, it was found that the Knowledge Management dimension that needs to be improved is knowledge sharing. Organizations can create programs to foster a culture of knowledge transfer among employees, for example by holding FGDs and creating an applicable knowledge sharing system that can involve all employees in the institution/organization.

2. Green commitment

Based on the research, the dimension of green commitment that needs to be improved is continuance commitment. Programs that can be made by organizations are to improve the reward and participation system of employees so that employees can have a high commitment to the organization and do not easily leave the organization.

3. Employee green behaviour

Employee green behaviour can be further improved by paying attention to the efficiency dimension. Programs that can be done by making savings related to the use of natural resources in work. 
4. Sustainable corporate performance

To maximize sustainable corporate performance, organizations need to develop programs related to sustainable social. Programs that can be carried out by companies are for example by implementing corporate social responsibility.

5. Future research is expected to explore other variables that affect sustainable corporate performance.

\section{ACKNOWLEDGMENT}

Authors are thankful to University of Ngurah Rai and University of Mercu Buana for document support to carry out this research.

\section{REFERENCES}

Abdelghafour, A., Hailat, S., Al-Jaradat, M., Bataineh, O. (2018), Green organizational identity and environmental commitment in higher education. International Journal of Business and Social Science, 9(10), 87-93.

Ali, S., Salehzadeh, R., Panahi, R., Abolghasemian, S. (2018), Multiple pathways linking environmental knowledge and awareness to employees' green behavior. Corporate Governance: The International Journal of Business in Society, 18(1), 81-103.

Bhupendra, K.V., Sangle, S. (2015), What drives successful implementation of pollution prevention and cleaner technology strategy? The role of innovative capability. Journal of Environmental Management, $155,184-192$.

Bilal, A., Umrani, W.A. (2019), Corporate social responsibility and pro-environmental behavior at workplace: The role of moral reflectiveness, coworker advocacy, and environmental commitment. Corporate Social Responsibility and Environmental Management, 27(1), 109-125.

Boiral, O., Paillé, P. (2011), Organizational citizenship behaviour for the environment: Measurement and validation. Journal of Business Ethics, 109(4), 431-445.

Daily, B.F., Bishop, J.W., Govindarajulu, N. (2009), A conceptual model for organizational citizenship behavior directed toward the environment. Business and Society, 48, 243-256.

Dalkir, K. (2011), Knowledge Management in Theory and Practice. Cambridge: MIT Press.

Ghabash, F.R., Kareem, J.M., Al-Birki, H.H.H. (2018), The interactive role of organizational learning in the relationship between modest leadership and employee green behavior strategy. The Journal of Social Sciences Research Academic Research, 4, 36-43.
Ghozali, I. (2014), Aplikasi Analisis Multivariate Dengan Program IBM SPSS 21 Update PLS Regresi. Semarang: Badan Penerbit Universitas Diponegoro.

Jansson, J., Nilsson, J., Modig, F., Vall, G.H. (2017), Commitment to sustainability in small and medium-sized enterprises: The influence of strategic orientations and management values. Business Strategy and the Environment, 26, 69-83.

Morrow, P.C. (2011), Managing organizational commitment: Insights from longitudinal research. Journal of Vocational Behavior, 79, 18-35.

Nejati, M., Shahbudin, A.S.B., Amran, A.B. (2010), Putting sustainability at the core of knowledge management performance evaluation system. Journal of Organizational Knowledge Management, 2010, 756961.

Norton, T.A., Zacker, H., Ashkanasy, N.M. (2014), Organisational sustainability policies and employee green behaviour: The mediating role of work climate perceptions. Journal of Environmental Psychology, 38, 49-54.

Ones, D.S., Dilchert, S. (2012), Environmental sustainability at work: A call to action. Industrial and Organizational Psychology, 5(4), 444-466.

Qaisar, I., Hassan, S.H., Akhtar, S., Khan, S. (2018), Employee's green behavior for environmental sustainability: A case of banking sector in Pakistan. World Journal of Science, Technology and Sustainable Development, 15(2), 118-130.

Robbins, P.S., Judge, T.A. (2009), Organizational Behavior. $13^{\text {th }}$ ed. Upper Saddle River, New Jersey: Pearson Education, Inc.

Rosemary, V.D.M., Sinnappan, S. (2008), The role of knowledge management in an organisation's sustainable development. In: Proceedings of the Knowledge Management International Conference. p1-6.

Thanita, K. (2017), The model of corporate social responsibility, organizational commitment, and employee green behavior. UTCC International Journal of Business and Economics, 9, 17-38.

Toha, T., Lenny, C.N. (2019), Analysis Effect of Green Commitment, Green Transformational Leadership and Job Satisfaction to Employee Green Behavior: Concept Approache. Prosiding Seminar Nasional Peningkatan Mutu Perguruan Tinggi.

Vasja, R., Meško, M., Bach, M.P., Bertoncelj, A. (2014), Impact of Knowledge Management on Sustainable Development in the Innovative Economy. Business Systems Laboratory- $2^{\text {nd }}$ International Symposium, Systems Thinking for a Sustainable Economy. Advancements in Economic and Managerial Theory and Practice.

Wijethilake, C., Munir, R., Appuhami, R. (2017), Strategic Responses to Institutional Pressures for Sustainability: The role of management control systems. Accounting Auditing and Accountability Journal, $30(1), 1$. 